\title{
16. Communication, Logistics and Inter-Agency Partnerships in the Eastern Highlands Provincial Electorate
}

\author{
Michael Unage
}

With the introduction of limited preferential voting (LPV), and the late legislative change to voting procedures in November 2006, many predicted that the 2007 general election would be a failure. Nonetheless, there was general satisfaction with the election outcome, with election-related violence in the Highlands down significantly from 2002 levels. Among factors contributing to electoral success, communications, logistics and inter-agency partnership were critical. This paper examines issues of communications, logistics and interagency partnership in the Eastern Highlands provincial electorate.

\section{Background}

Eastern Highlands is one of the 19 provincial electorates in the country. It shares borders with Morobe, Madang, Simbu and Gulf provinces. Eastern Highlands has eight open electorates-Daulo, Goroka, Unggai-Bena, Lufa, Henganofi, Okapa, Kainantu and Obura-Wonenara (Figure 16.1). At the 2000 census, Eastern Highlands had a population of 432,972. In 2007 the total number of votes polled in the provincial electorate was 354,495.

There are 24 local-level governments (LLGs) in the province: two urban LLGs (Goroka Urban and Kainantu Urban) and 22 rural LLGs. Population is concentrated in the flat lands around Kainantu and Goroka, reflecting the gravitation of people towards the urban areas. Goroka town was established in 1939 and became the major administrative and commercial centre of the province.

The province has rich temperate valleys and ridges, which attracted the attention of early gold prospectors such as Mick Dwyer and Mick Leahy and now support a thriving arabica coffee industry. Coffee, 'the money that grows on trees', is the lifeblood of Eastern Highlands Province. 


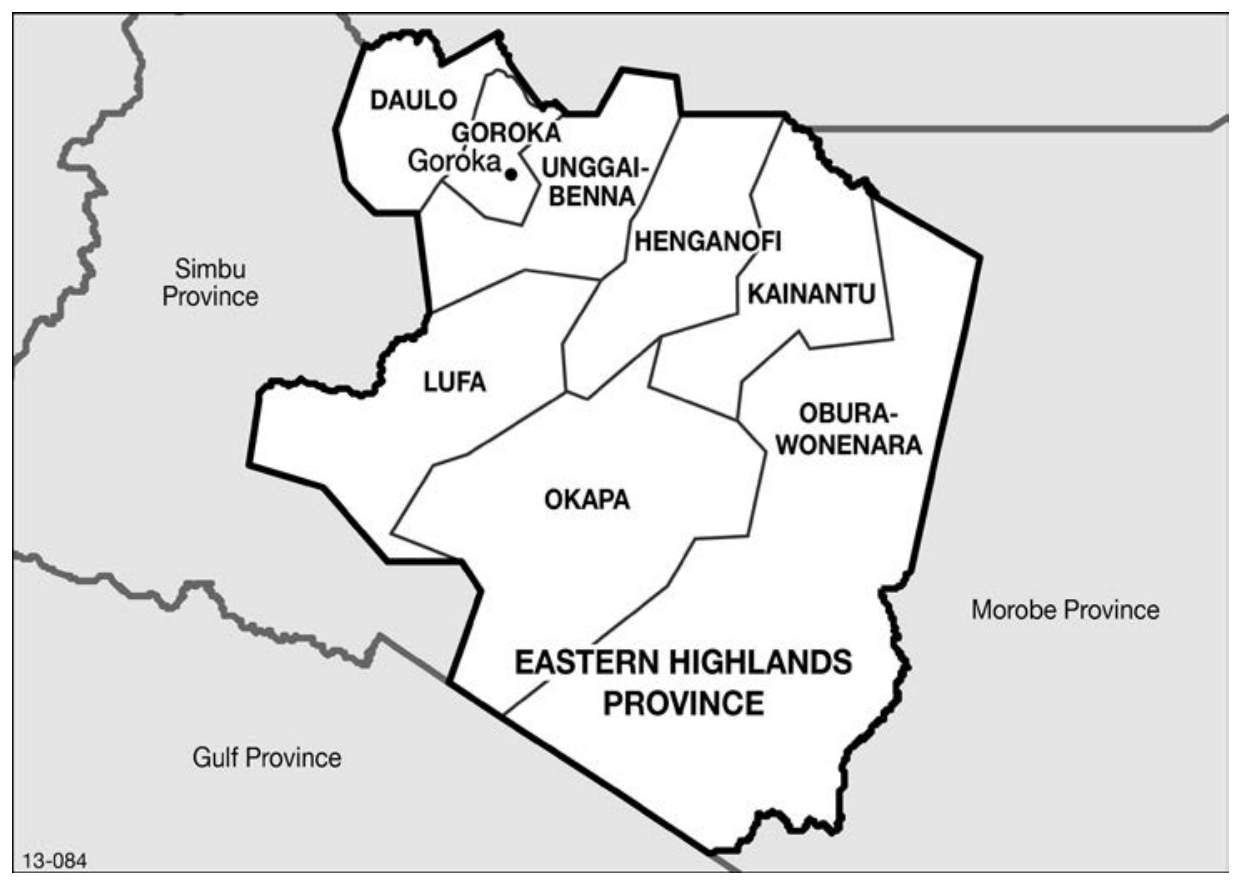

Figure 16.1: Eastern Highlands Province open electorates

Data for the study of the Eastern Highlands provincial electorate was gathered through unstructured interviews with candidates, polling officials and voters. The interviews specifically sought both qualitative and quantitative information on communication, logistics and inter-agency partnerships.

\section{LPV awareness}

Though there was preference voting in Papua New Guinea before independence, most eligible voters were not familiar with the LPV system. It was therefore essential to conduct an awareness campaign before the commencement of polling. Several agencies were involved in this.

The National Broadcasting Corporation (NBC) in Goroka did an outstanding job in communicating electoral information through its radio network. Time was allocated for election awareness at 7.15 pm every Tuesday and Thursday, which was considered prime time. In the program, electoral officers explained in detail what people needed to know about the LPV system, and answered queries people had about their right to vote without undue influence from candidates, supporters or political parties. The Australian Agency for International Development also funded a radio commentary and a drama program on elections 
and HIV/AIDS (respectively 'Autim tok na Tingting' and 'If to You'), as well as 'HIV/AIDS spots' at least 12 times a day. These were broadcast from late February till the end of August 2007.

The Papua New Guinea Electoral Commission (PNGEC), with the help of local public servants, did three lots of LPV awareness throughout Eastern Highlands Province. Election materials, produced by the PNGEC, were distributed by teams which visited rural areas. Mock elections were conducted. In a few electorates, the returning officers conducted training of trainers for LPV awareness.

A few civil society groups, funded under the Electoral Support Program, did LPV awareness in the Eastern Highlands. These included the Goroka Community Development Agency, Women in Agriculture, Pamusa Community Development Assistance, and Lower Unggai Community Development. Though the scope of the activity was limited, they managed to get the message across to people who might not otherwise have been reached.

It was also reported that many of the candidates took up the responsibility for educating voters on the LPV system, out of fear that their votes might otherwise be informal.

Observers reported that residents of Goroka and Kainantu towns had the opportunity to attend LPV awareness carried out by civil society groups, but LPV awareness did not penetrate many rural areas of the provincial electorate despite requests from rural voters. Those who carried out LPV awareness said that they were not adequately resourced by the PNGEC to carry out informative awareness.

Few candidates appear to have talked about HIV/AIDS as part of civic awareness. In many polling places, there was no display of HIV/AIDS materials.

\section{Electoral roll}

The most important activity leading up to the 2007 general election was the electoral roll update. The update was done in two phases. First, four enumerators, accompanied by local councillors, went from village to village enrolling people over 18 years of age. The enrolment was then checked by the district supervisors and sent to Port Moresby for the printing of preliminary rolls. The preliminary rolls were given to returning officers for checking and sent back to the PNGEC's head office. Secondly, in early 2007, the electoral roll was sent out for verification and update, a process which was controlled by 
returning officers. The verified forms were then sent to Port Moresby for the final printout, which arrived before the start of polling. Civil society groups were not involved in the update of the electoral roll.

Many voters did not register their names on the electoral roll out of ignorance or because the enrolment teams did not visit all residential areas at the ward level. Moreover, observers reported that many eligible voters did not fill in the claim for enrolment form when enumerators did visit their village. Consequently many voters were unable to cast their votes and people raised concerns that the electoral roll did not have a complete listing of people. On the other hand, in some newly created polling places there were said to be 'ghost' names on the rolls.

Some observers claimed that the electoral roll was hijacked by greedy politicians, councillors, and candidates who did what they could to ensure the roll served their interests. The fact that candidates had tampered with the electoral roll suggests that politics in the province continues to be aggressively competitive. Concentrations of voters residing in Goroka and Kainantu towns means that clan loyalty has been somewhat weakened. Candidates now have to rely on cross-ethnic votes if they are to win. Abuse of the electoral roll is seen as one way of ensuring a win.

\section{Training}

In the 2007 election, training was especially important because of the new voting system. Training was conducted by returning officers in their respective electorates in the lead-up to the election. At least five training sessions were conducted, namely: a two-day session for presiding officers, which included setting up polling places and holding mock elections; a day's training for polling clerks, doorkeepers, and ballot box guards; briefing of scrutineers on LPV and counting; a workshop for candidates; and a two-day training session for counting officials.

Training of polling officials by the PNGEC, however, was generally seen as inadequate. Consequently, delays and confusion were experienced in counting. The Obura-Wonenara electorate did poorly in the regional count, delaying the counting by a day or so as papers were rechecked. The team supervisor had only had a two-hour training session. He stated that he did not know exactly what was expected of him. Only 200 of 700 counting officials (28 percent) received training in the counting and elimination aspects of the LPV, which rendered the integrity of the elections vulnerable to challenge. 


\section{Transport}

Some 240 hired vehicles, and six fixed-wing aircraft and helicopters from the Papua New Guinea Defence Force (PNGDF), the police, the Summer Institute of Linguistics, and commercial contractors, were employed to transport election materials and personnel. Bad weather and the late arrival of helicopters caused a few delays. Some polling officials had to walk for days to reach remote polling areas. One polling team was picked up on the Madang Highway when a helicopter failed to pick them up from a remote polling place.

The placement of aviation fuel at strategic points curtailed unnecessary trips to Goroka for refuelling of helicopters, and the availability of the Summer Institute of Lingustics's aircraft assisted in accessing remote polling places.

\section{Security}

In addition to regular police from the Eastern Highlands, two mobile squad units (from Kerowagi and Laiagam) were deployed to the Eastern Highlands in advance to polling, and other police contingents from Port Moresby were deployed in time for polling. Besides the police, the PNGDF's A Company from Lae was deployed during and after polling, and members of the Correctional Services from Bomana provided security assistance. Casual security personnel were also employed at the counting centre.

However, police logistics were often a problem during polling. Police did not accompany polling teams to all polling places, and not all polling stations had a police presence. Especially in the towns, a heavy security presence provided some control over the voting, but in remote places the security presence was inadequate to guarantee voters' security and free choice. Instead, village court officials took responsibility for security in many remote polling places.

Notwithstanding these constraints, there was general peace and order, and no weapons were seen in the hands of civilians during the campaign or at polling.

\section{Electoral costs}

The cost of conducting the election in the Eastern Highlands has been estimated at around K3.8 million (Table 16.1). 
Election 2007: The Shift to Limited Preferential Voting in Papua New Guinea

Table 16.1: Election costs in Eastern Highlands Province ${ }^{\mathrm{a}}$

\begin{tabular}{lr}
\hline Expenditure item & Cost (K'000) \\
\hline Security & 202 \\
Transport & 1124 \\
Communication (mainly payments to NBC and Telikom) & 26 \\
Printing of electoral roll & 36 \\
Logistics (hire of premises, electricity, etc.) & 195 \\
Wages and allowances & 1766 \\
Activity grant to electorates (for awareness, training etc.) & 453 \\
Total & 3802 \\
\hline
\end{tabular}

$a$ These may not be final figures in all cases. The costs of the electoral roll update are not included, but were probably in the order of $\mathrm{K} 300,000$.

\section{Polling}

Officially, polling in the Eastern Highlands commenced on 9 July, though in a few remote areas, polling began some days later due to transport difficulties and bad weather. Polling was not conducted in a few places, due to fighting unrelated to the election.

There were 663 polling teams, with 663 ballot boxes each for the provincial electorate and the open electorates. Ballot boxes for each electorate were colour-coded, in an attempt by the provincial election manager to remove any suspicion that election officials were allowing candidates to produce their own ballot boxes and ballot papers.

Polling was generally orderly, though at many polling stations polling and security officials gave into the demands of the voters and did not confirm names on the roll before allowing voters to cast their votes. In some polling places, there were reports of multiple voting and some underage voting. Frequently people were not able to cast their votes freely, because voting compartments were controlled by youths who told voters to vote for certain candidates; the security presence was inadequate to prevent this. In many places polling became disorderly towards afternoon.

\section{Counting}

Counting for all electorates in the Eastern Highlands was conducted at the National Sports Institute. Stalls were constructed for each electorate, and the 
regional stall comprised eight compartments for the primary count. All tally rooms had phone connections. Ballot boxes were taken to the counting centre on designated vehicles, and kept under close scrutiny.

Security arrangements at the counting centre were exceptional, with PNGDF personnel, police mobile squads, local police from Goroka, and casual security personnel providing security. Meticulous checks were conducted at the entrance to the counting centre, even for counting officials. Mobile phones were confiscated at the gate. Scrutineers had a good view of the counting process. No scope was left for election fraud. Indeed no one would have dared to hijack the process, even at gunpoint. There were, however, complaints that security was excessive and that many electoral officials were treated with disrespect.

Despite the recent introduction of the LPV system, the counting process was generally good, though some problems emerged. The primary count was fairly straightforward except for Obura-Wonenara, which delayed the provincial count by a day while papers were rechecked. As the count proceeded, however, the scrutineers and campaign officials of losing candidates tried to freeze the counting, organizing informal protest meetings outside the counting venue. Sitting member Malcolm Kela Smith led from the start by a big margin, which created strong suspicion among other candidates and their supporters and scrutineers.

Presiding officers sometimes failed to provide polling summaries. Consequently, figures were not available for verification. One presiding officer was questioned by police for holding on to returns. Counting was continually disrupted by scrutineers because of discrepancies between the totals on the counting board and those on the presiding officers' returns.

A number of ballot papers were found in the wrong boxes (in most electorates, some ballot papers for open electorates were mistakenly put in the boxes meant for provincial electorates, and those for provincial electorates in the boxes meant for open electorates). These were sorted out and accepted, but took up time and effort. Further, about a third of the counting officials were laid off before the elimination counts, prompting complaints from them that they had been contracted for 21 days to do the counting. Checking of ballot papers took at least two days, during which more informal ballot papers were discovered.

There were also miscounts of ballot papers, and miscalculation of figures. Discrepancies emerged between the final figures at the end of each exclusion and the total number of ballot papers per box, such that adjustments had to be made on nearly every exclusion. Informal ballot papers and unaccounted ballot papers continued to surface. 


\section{Communication}

Communication between the election manager for Eastern Highlands Province and the returning officer was good; directions and instructions were received by the returning officer without any major difficulty. As a result the entire election process - from nominations to counting — was relatively peaceful and orderly. The chain of communication to assistant returning officers was also good. At the Lopi polling station, for example, all voters who turned up to vote were able to vote in secrecy and there was no multiple voting.

Polling officials understood their respective roles. Presiding officers allowed those voters who were still on a queue between $5 \mathrm{pm}$ and $6 \mathrm{pm}$ to cast their votes; this brought satisfaction to the voters, whose patience had not been in vain.

Election results were promptly communicated by the election manager to the PNGEC headquarters and the Media Centre in Port Moresby. There was generally good communication between the election manager and the returning officer and police, and between police and the PNGDF. Landline phones and faxes were available for all agencies to use according to their needs.

\section{Logistics}

Transport and security arrangements were generally in place for the protection of ballot boxes and papers, and for their prompt transport to the appropriate LLG distribution points or police stations. Police were on hand to provide escort for the vehicles carrying the ballot boxes and papers; polling officials and scrutineers usually accompanied the ballot boxes. The returning officers took custody of any unused ballot papers, which were then transported with police escort to the appropriate LLG distribution point or police station.

\section{Inter-agency partnership}

Partnerships at the national level were well in place through the Interdepartmental Electoral Committee (IDEC), chaired by the Registrar of Political Parties. Through IDEC, directions filtered down to the election managers at the provincial level. Partnerships between PNGEC officials, police, PNGDF, LLGs, ward councillors, civil society, and local communities in the Eastern Highlands can be described as cooperative, friendly, and conducive to peaceful elections. 
Information necessary for the sound conduct of duties for each agency was duly conveyed, allowing for the effective carrying out of activities at each stage of the election process.

In consequence, most voters in the Eastern Highlands were pleased with the relative peace and order of the elections and the freedom to move around as well as exercise their democratic right to vote.

\section{Electoral outcomes}

\section{The results}

Thirty-five candidates stood for the Eastern Highlands provincial electorate, of whom eight were endorsed by political parties (see Table 16.2 at the end of this chapter).

Malcolm Kela Smith, the sitting member led in the primary count, with 77,254 votes, and eventually won with a final tally of 130,427 which was 37.7 percent of total formal votes. The runner-up, both in the primary and final tally, former member of parliament Barry Holloway, scored 25,790 and 72,219 respectively. John Yogio came third with a primary vote of 22,511 and a final vote of 55,755. Julie Soso Akeke, the only female candidate contesting the regional electorate, polled 16,651 votes, placing her in eighth position in the primary count; she was eliminated in the thirtieth count, with a total vote of 34,164 .

In the primary count of the Eastern Highland Regional seat, 355,203 ballot papers were cast, of which only 8860 ( 2.5 percent) were informal. It appears, therefore, that the introduction of LPV voting, in the Eastern Highlands at least, did not result in a significant informal vote.

At the thirty-second elimination, the remaining 'live' ballot papers numbered $258,4011^{1}$ that is, only 25.4 percent of formal votes had been exhausted. This suggests that voters in the Eastern Highland directed their preferences strongly towards the top three candidates - unlike other electorates that saw more than 50 percent of ballot papers exhausted. Thus, we might infer that people in the Eastern Highlands have understood the intention of the preferential voting system by distributing preferences among the stronger candidates.

1 The figure for total ballot papers remaining in count on the official form 66B was 261,146; however, this is not the correct sum of the three remaining candidates' votes. We have used the recalculated figure because the former would not have Malcolm Kela Smith winning with an absolute majority. 
Disputed election results imply malpractice and election anomalies. In the Eastern Highlands in 2007, though six election petitions were registered, only two went for pre-trial, the other four being dismissed by the court. The implication would seem to be that the elections were accepted as generally fair.

Since there was no significant election-related violence, we can surmise that people were generally content with the way election was conducted; the LPV system may have contributed to this.

\section{Assessing the outcomes}

\section{The change from first-past-the-post to limited preferential voting}

The shift to a LPV system had a major impact on election outcomes. The general peace in the Eastern Highlands during the elections can probably be attributed to the LPV system. Clan boundaries opened up for other candidates to enter, and parochial candidates were encouraged to go to other clans to campaign for preference votes. Intense negotiation and vote trading was evident everywhere. Voters felt free to move from one candidate's domain to another's, and the hijacking of ballot papers was uncommon in 2007. The general consensus was that the 2007 election was better than that in 2002 and that LPV contributed to this.

LPV likewise made electoral logistics easier, as polling places were more peaceful and foul play at the counting centres was reduced - it was reported that several counting officials rejected bribes to rig the process, knowing that it would be difficult if not impossible to do so. LPV helped people in the electoral process do the right thing.

\section{Planning, consultation and participation}

Consultation and involvement of people was evident in the work of the provincial steering committee and the participation of key stakeholders in the electoral process. The Eastern Highlands election manager had long experience with the PNGEC, and took the initiative when needed. When funds were not forthcoming, he personally travelled to PNGEC headquarters requesting their release. The election manager enlisted a group of first-time returning officers whose enthusiasm and motivation to prove their worth contributed to the effective execution of election plans.

The electoral steering committee was chaired by the deputy provincial administrator who was also responsible for the discipline of local public servants. Thus professional conduct was maintained and electoral fraud by public servants minimized. 
Key local stakeholders were members of the provincial steering committee, and the involvement of civil society in governance education and LPV awareness may have contributed to the successful outcome.

There was also evidence of a change in people's participation; with less feasting and campaigning, they took the time to educate themselves about the electoral process, especially the LPV system.

\section{Wider dissemination of information, increased popular understanding of the electoral process, and improved communications}

The NBC in Goroka took an active role in the electoral awareness campaign and in disseminating information to the local people. The PNGEC also promoted LPV awareness, and many candidates took on the responsibility of educating voters about the new electoral process. During the election, the accessibility of a satellite phone for all returning officers facilitated communication with the election manager.

\section{Better logistic support}

For the first time, provincial treasuries were used to process cheques, making disbursement of funds to election tasks more convenient. Other notable successes in logistics in the Eastern Highlands were the separate ballot boxes for the regional and the open electorates, making counting less tedious, and the colour coding of the ballot boxes which reduced the level of suspicion of foul play. The set-up of the counting centre was another remarkable achievement: it provided full transparency in the counting of ballots. Bad weather and delays in other highland provinces caused minor disruption to the transportation of polling teams; otherwise transport arrangements were excellent.

But despite some remarkable successes, election management needs to be improved in several areas.

\section{The electoral roll}

A disjunction was observed between the intention and the practice of the electoral roll. Ethnic bloc voting frequently replaced the electoral roll, and voters felt that calling and checking names was time consuming (and LPV voting needed time). Hence, as reported by domestic observers, a majority of the polling places in the Eastern Highlands did not utilize the electoral roll. This needs to be examined. 


\section{Limited preferential voting awareness}

Despite the efforts of those communicating the LPV message, most observers reported that LPV awareness did not penetrate into many rural communities, where few people own radios and many people are illiterate. Patrols on foot by existing community groups may be more effective.

\section{Assisting illiterate voters}

Given the number of illiterate voters, one might be surprised at the low informal vote. The explanation is that illiterate voters were frequently assisted by educated people. However, it was noted by observers that in some polling places a few people marked the ballot papers for all the voters. And when votes were counted it was noted that in a few ballot boxes papers appeared to have been marked by the same hand. Perhaps this is an indication that many of the illiterate voters did not exercise a completely free choice.

\section{Ballot papers}

The fact that the provincial and open ballot papers looked alike caused some problems, with voters marking their choices for provincial candidates on open ballot papers and vice versa, or putting correctly marked ballot papers in the wrong ballot box. This might be fixed by using differently coloured ballot papers for open and provincial electorates.

\section{Training}

Training for counting officials was not adequate and this resulted in a slow start to counting. Some officials were briefed for less than one hour before counting commenced. This particularly affected the distribution of preferences. There were discrepancies in the count where figures did not balance and had to be reworked. Partly because of this, counting was continually disturbed by scrutineers. Two days of checking revealed more informal ballot papers, miscounts of ballot papers, and miscalculation of figures. Adjustments were consequently made on each exclusion. The official final count of the PNGEC differs somewhat from the records kept by domestic observers.

\section{Security arrangements}

Despite the heavy security presence in Goroka and in the district headquarters, security was inadequate to guarantee voters' security and free choice in remote rural polling places. There were several reasons for this: the security concerns in Southern Highlands and Enga provinces meant that less consideration was given to Eastern Highlands Province where election violence is comparatively low; the election-related problems in the four other Highlands provinces delayed 
the arrival of police in time for polling in the Eastern Highlands; for the first time, police logistics for the provinces were drawn up in Port Moresby, which resulted in a lack of proper implementation in the provinces; and some lack of communication between police and returning officers posed problems for the movement of ballot papers during polling.

\section{Management and disbursement of funds}

Allegations of misappropriation of funds for election purposes recur in Papua New Guinea elections. Eastern Highlands in 2007 was no exception. Long after the election many people and organizations who had provided goods and services claimed they had not been paid, including police personnel engaged in the election who claimed not to have received due allowances.

\section{Regionalizing electoral responsibilities}

The planning of electoral operations at headquarters in Port Moresby seems to result in delays and frustration at the provincial level. Frequent trips to Port Moresby by the provincial election manager, to sort out logistic problems, and his consequent absence from the province, affected the planning of the election in Eastern Highlands. There is perhaps scope for a greater decentralization of electoral responsibilities in the interests of efficiency. This might include the appointment of a full-time electoral official in each electorate.

\section{Obstacles to electoral administration}

No matter how much planning and resources are put into making elections a success, two factors in particular continue to hinder free and fair elections in the Eastern Highlands (and other parts of Papua New Guinea): clan politics and corruption.

\section{Clan politics}

In many parts of Papua New Guinea the pressures stemming from clan solidarity outweigh consideration of individual rights. Electorally, this is manifested in ethnic bloc voting and 'line up' voting; in manipulation of the electoral roll; in double or multiple voting; in insisting that voters give their first preference to a parochial candidate, and in inducing fear and intimidation. These were in evidence in the Eastern Highlands in 2007. The problem requires a broad response, including governance and human rights education conducted by civil society groups, giving special consideration to the Highlands Region, strict 
enforcement of the secrecy of the vote, with village courts having jurisdiction to prosecute offenders, and an increased police presence, in conjunction with community security arrangements, during elections.

\section{Corruption}

Not only has money been used increasingly to buy people's votes, more disturbing is an emerging tendency for candidates and their supporters to attempt to buy out the election process, or bribe electoral officials to rig the process. Many cases of bribery were reported in the 2007 election by domestic observers. A statement by the acting provincial returning officer of Eastern Highland confirmed this: 'The 2007 general election', he said, 'was a success; however, we cannot ascertain that it was a free and fair election' ${ }^{2}$ Severe penalties must be imposed on candidates offering bribes and on polling officials accepting bribes.

\section{Conclusion}

The 2007 elections were generally seen as being better than the 2002 elections in Eastern Highlands Province.

The legislative change from first-past-the-post to LPV appears to have resulted in a shift in attitude and election practice, and, as such, improved election outcomes in 2007, though minor legislative changes may be needed to close some loopholes.

Efficient communications and logistics, and effective inter-agency partnerships at the national and provincial levels are an integral part of electoral governance. Although the election in the Eastern Highlands in 2007 was not perfect, communication between the PNGEC headquarters in Port Moresby and the provincial election manager in Eastern Highlands Province, and between the election manager and polling officials, contributed significantly to the success of the election in the province. Aside from efficiently coordinated logistics, an effective partnership between all relevant agencies and civil society and community groups is important for sound elections; people must take ownership of the election and, in the process, understand the meaning of voting, and why it is important to elect good leaders. The pre-polling, polling and post-polling periods were relatively peaceful in Eastern Highlands Province, the latter an indication that people have accepted the outcome.

2 Interview with Kusindel Kalowai, acting provincial returning officer of Eastern Highlands Province. 
16. Communication, Logistics and Inter-Agency Partnerships in the Eastern Highlands Provincial Electorate

\section{Appendix}

Table 16.2: Voting statistics for Eastern Highlands Province, 2007 election

Number of registered voters

Total ballots cast

Informal votes

Total allowable ballot papers

Total ballot papers remaining in count

Total votes distributed

Exhausted ballot papers

Absolute majority $(50 \%+1)$
383,471

355,203

$8,860 \quad(2.5 \%$ of ballots cast)

346,343

258,401

220,788

87,942 (25.4\% of allowable ballots) 
Election 2007: The Shift to Limited Preferential Voting in Papua New Guinea

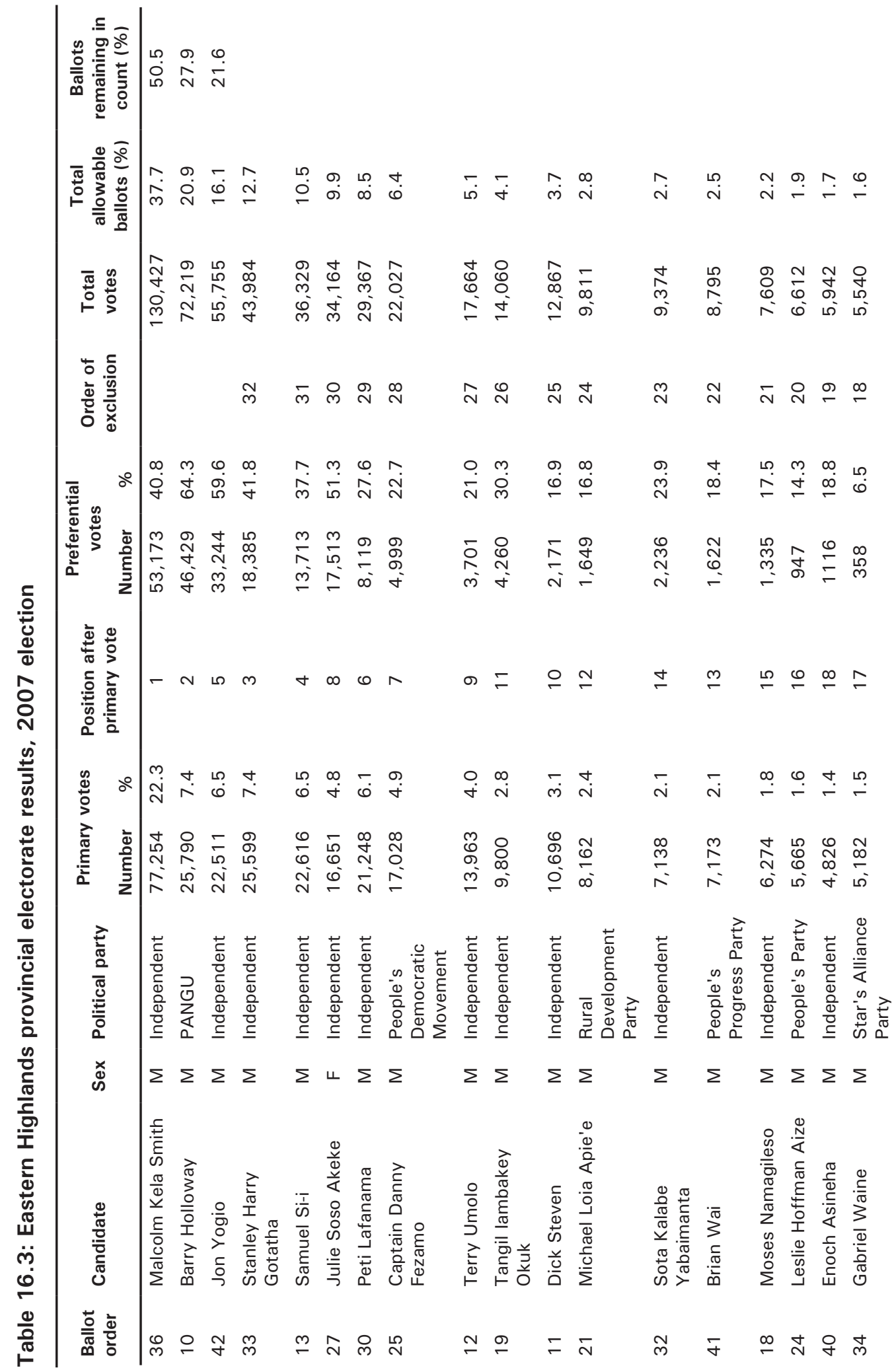


16. Communication, Logistics and Inter-Agency Partnerships in the Eastern Highlands Provincial Electorate

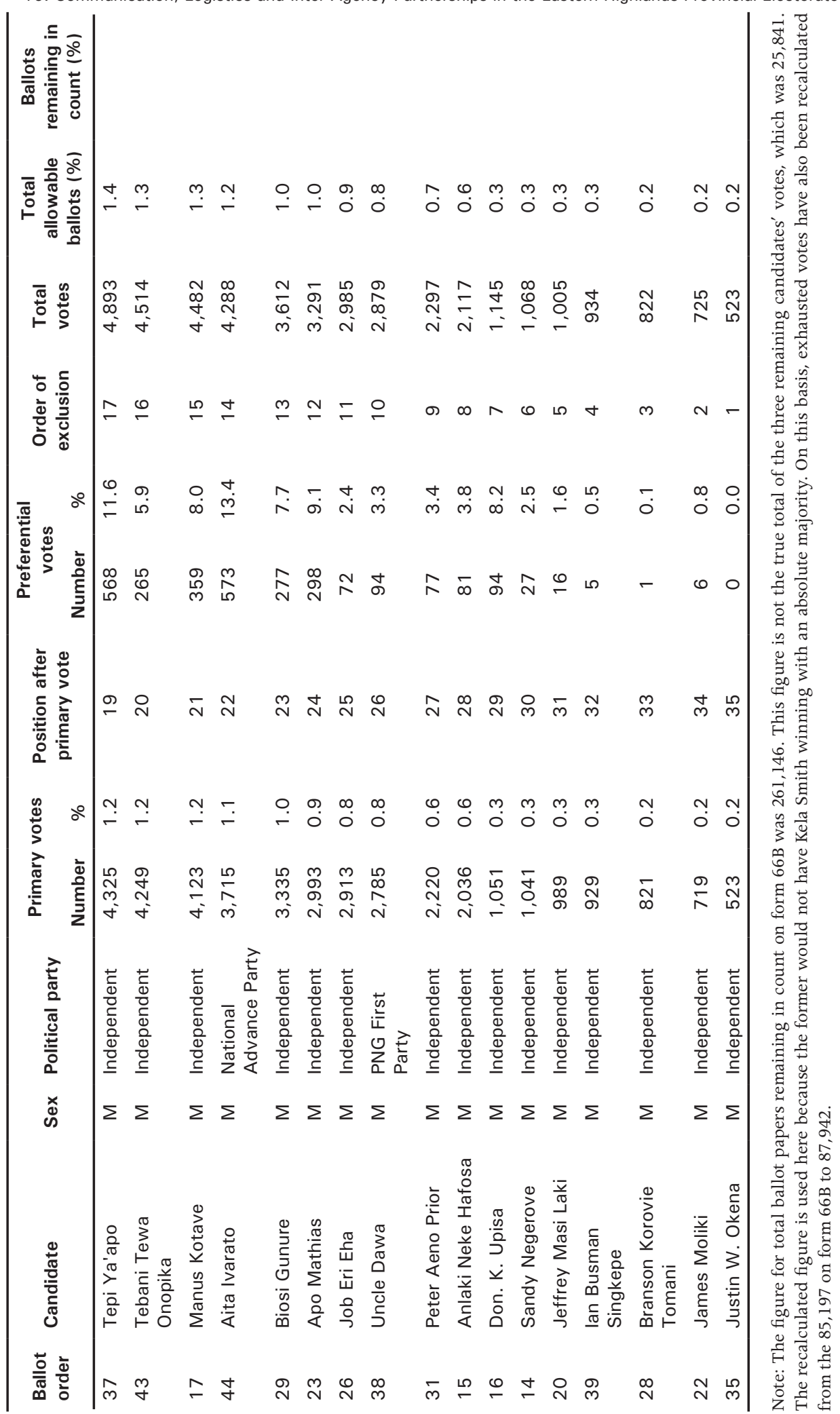

